\title{
Field evidence for the exposure of ground beetles to Cry1Ab from transgenic corn
}

\author{
Claudia ZWAHLEN and David A. ANDOW \\ Department of Entomology, University of Minnesota, 219 Hodson Hall, St. Paul, MN 55108, USA
}

Non-target organisms associated with the soil might be adversely affected by exposure to the Cry $1 \mathrm{Ab}$ protein from Bacillus thuringiensis (Bt) in transgenic corn (Zea mays L.). To check for such exposure, we used ELISA to test for Cry1 $\mathrm{Ab}$ in ground beetles collected live from fields with $B t$ corn residues and $B t$ corn $(B t / B t), B t$ corn residues and non- $B t$ crops (Bt/non- $B t)$, or non- $B t$ corn residues and non- $B t$ crops (non- $B t /$ non- $B t$ ). In fields with $B t$ corn residues (Bt/Bt and $B t /$ non-Bt), Cry1Ab was present in all seven species of ground beetles examined (Agonum placidum, Bembidion rupicola, Clivina impressefrons, Cyclotrachelus iowensis, Harpalus pensylvanicus, Poecilus chalcites, and Poecilus lucublandus). For the two most abundant species, $P$. chalcites and $P$. lucublandus, the proportion of beetles with Cry1 Ab was significantly higher in Bt/Bt fields (0.50-1.0) and Bt/non$B t$ fields $(0.41-0.50)$ than in non-Bt/non-Bt fields (0.0). This is the first field evidence that some ground beetle species are exposed to Cry1 Ab. The implications of exposure on the performance of these non-target organisms are unclear.

Keywords: genetically modified Bt crops / Bacillus thuringiensis / Carabidae / risk assessment / ELISA (enzyme-linked immunosorbent assay)

\section{INTRODUCTION}

The large-scale cultivation of transgenic crops expressing Bacillus thuringiensis $(B t)$ proteins targeted against various lepidopteran (e.g., Cry1Ab in corn, Cry1Ac in cotton) and coleopteran pests (e.g., Cry3Bb1 in corn) may possibly have direct or indirect effects on non-target organisms, potentially changing food web dynamics in agricultural ecosystems. Direct effects involve interactions of the transgene product with another organism (e.g., lethal or sublethal effects of the Cry $1 \mathrm{Ab}$ on non-target species) while indirect effects are the result of interactions subsequent to a direct effect (e.g., natural enemies are less abundant in $B t$ corn fields due to a lower abundance of prey species). The existence of such effects requires both exposure to the transgene product and an ecological consequence of exposure. In the soil ecosystem, the detection of ecological consequence of exposure to $B t$ corn is difficult because sampling is time consuming and there is high variability among samples.

In this paper we examine the first part of this issue by focusing on possible exposure of ground beetles to
Cry1Ab from Bt corn (Zea mays L.) in the field. Most, if not all, ground beetles are omnivorous and/or polyphagous (Lövei and Sunderland, 1996; Toft and Bilde, 2002). If the beetles are exposed to Cry1Ab, the food source should be corn residues (Zwahlen et al., 2003a; 2003b), living corn plants, prey containing Cry1 Ab (Dutton et al., 2002; Head et al., 2001; Raps et al., 2001; Wandeler et al., 2002), or any combination of the three. Studies like the one we present here are a first step towards characterizing potential risks of transgenic plants in the field on non-target organisms. In this paper, we suggest that ground beetles may acquire Cry1 Ab either directly or indirectly from $B t$ corn residues. Our hypotheses were: (H1) ground beetles in fields with Cry1 Ab Bt corn residues planted with either $B t$ corn or non-Bt crops will contain Cry1 Ab (either residue, the living crop, or both are sources of Cry1 $\mathrm{Ab}$ ); and (H2) ground beetles in fields with Cry $1 \mathrm{Ab} B t$ corn residues planted with non- $B t$ crops will contain Cry1 Ab, thus suggesting that $B t$ corn residues are a significant source of Cry1 Ab in ground beetles.

\footnotetext{
* Corresponding author: claudia.zwahlen@gmx.net
} 
Table 1. Bt protein exposure. ELISA of adult ground beetles found in the three different field types $B t /$ non- $B t, B t / B t$, and non- $B t /$ non- $B t$. Given is the mean \pm SE concentration of Cry $1 \mathrm{Ab}$ in ng. $\mathrm{g}^{-1}$ fresh tissue of ground beetles that contained the $B t$ protein, and the number of samples tested positive/number of samples tested $(n)$. Samples represent individuals except for $B$. rupicola where the total number of individuals tested per field type is given in parentheses. Hypotheses H1 (Bt/Bt and $B t /$ non- $B t v s$. non$B t /$ non- $B t)$ and $\mathrm{H} 2(B t /$ non- $B t v s$. non- $B t /$ non- $B t)$ were only tested for the species $P$. chalcites and $P$. lucublandus. Given are the results of the Fisher's exact test.

\begin{tabular}{|c|c|c|c|c|c|c|c|c|c|c|}
\hline "residues/plants: & $B t / B t$ & & $B t /$ non- $B t$ & & non- $B t /$ non- $B t$ & & 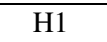 & & $\mathrm{H} 2$ & \\
\hline Species analyzed & ng Cry 1 Ab.g ${ }^{-1}$ & $n$ & ng Cry 1 Ab.g ${ }^{-1}$ & $n$ & ng Cry 1 Ab.g ${ }^{-1}$ & $n$ & $P$ & $d f$ & $P$ & $d f$ \\
\hline Agonum placidum & - & - & $13.4 \pm 11.2$ & $2 / 5$ & 0 & $0 / 2$ & - & - & - & - \\
\hline Bembidion rupicola & 0 & $0 / 1(1)$ & 12.9 & $1 / 2(8)$ & 0 & $0 / 2(6)$ & - & - & - & - \\
\hline Clivina impressefrons & - & - & 23.6 & $1 / 4$ & 0 & $0 / 1$ & - & - & - & - \\
\hline Cyclotrachelus iowensis & $20.9 \pm 12.6$ & $4 / 4$ & $34.7 \pm 14.6$ & $3 / 7$ & 1.0 & $1 / 4$ & - & - & - & - \\
\hline Harpalus pensylvanicus & 6.4 & $1 / 1$ & 0 & $0 / 1$ & 0 & $0 / 1$ & - & - & - & - \\
\hline Poecilus chalcites & $117.3 \pm 104.8$ & $2 / 2$ & $38.3 \pm 24.3$ & $10 / 20$ & 0 & $0 / 15$ & 0.0004 & 1 & 0.0016 & 1 \\
\hline Poecilus lucublandus & $47.9 \pm 19.2$ & $3 / 6$ & $27.5 \pm 15.8$ & $7 / 17$ & 0 & $0 / 10$ & 0.0148 & 1 & 0.0261 & 1 \\
\hline
\end{tabular}

To test the first hypothesis, we collected ground beetles in fields that contained $B t$ corn residues from the previous year and were planted with either $B t$ corn (referred to as " $B t / B t$ " for residues/plants) or a non- $B t$ crop (referred to as " $B t /$ non- $B t$ ") and compared these beetles to ones collected in fields containing non- $B t$ corn residues from the previous year that were planted with a non- $B t$ crop (referred to as "non- $B t /$ non- $B t$ "). To test our second hypothesis we compared the Cry1 Ab presence in ground beetles collected in $B t /$ non- $B t$ fields with beetles collected in non- $B t /$ non- $B t$ fields.

\section{RESULTS}

Samples from all seven species of ground beetles tested contained Cry $1 \mathrm{Ab}$ when collected in fields containing $B t$ corn residues (Bt/Bt and Bt/non-Bt) (Tab. 1). In contrast, only one individual of Cyclotrachelus iowensis from fields containing non- $B t$ corn residue (non- $B t /$ non- $B t$ fields) showed $B t$ protein exposure. This individual contained only $1 \mathrm{ng}$ Cry $1 \mathrm{Ab} . \mathrm{g}^{-1}$ beetle and may have been a false positive. The sample size was largest for Poecilus chalcites, Poecilus lucublandus, and C. iowensis with 37, 33, and 15 individuals, respectively, and much lower for the other four species, Agonum placidum, Bembidion rupicola, Clivina impressefrons and Harpalus pensylvanicus, with three to seven samples per species. We tested our hypotheses 1 and 2 only with the two most abundant species $P$. chalcites and $P$. lucublandus (Tab. 1).

The Fisher's exact test of hypothesis 1 (Bt/Bt and Bt/ non- $B t$ vs. non- $B t /$ non- $B t$ ) showed the Cry1Ab was present in a significantly higher proportion of $P$. chalcites and $P$. lucublandus from fields with $B t$ corn residue/plants than from fields with non-Bt corn residue and non- $B t$ crops (Tab. 1). These results suggest that exposure is associated with living Bt corn, Bt corn residues, or both.

The Fisher's exact test of our second hypothesis (Bt/ non- $B t v s$. non- $B t /$ non- $B t$ ) showed that a significantly higher proportion of $P$. chalcites and $P$. lucublandus contained Cry1 Ab from fields with $B t$ corn residue than from fields with non- $B t$ corn residue (Tab. 1). These results suggest that exposure is associated with $B t$ corn residues.

\section{DISCUSSION}

Our results are the first field evidence that ground beetles are exposed to Cry1 Ab from transgenic corn. All of the seven species tested were exposed when collected from fields with $B t$ corn residues. Our first hypothesis, that beetles in fields with $B t$ corn will contain Cry $1 \mathrm{Ab}$, is well supported by our finding that the Cry $1 \mathrm{Ab}$ was detected in a significantly higher proportion of $P$. chalcites and $P$. lucublandus, the two most common species, from fields with $B t$ corn than from fields without $B t$ corn. Laboratory feeding trials indicate that these two species may feed on armyworms (Pseudaletia unipuncta Haworth), which sporadically also occur as pests in corn (Clark et al., 1994). Both species are considered polyphagous predators of arthropods, but the degree of omnivory, if any, and the possible preferences among prey species in the field are poorly known.

Several pathways of exposure of ground beetles to the Cry1 $\mathrm{Ab}$ are possible, including feeding directly on corn residues or living plant tissue (see Hladilek, 2003; Toft and Bilde, 2002), or on prey containing Cry1 Ab (Kromp, 
1999; Toft and Bilde, 2002). Our results testing the second hypothesis suggest that the Cry $1 \mathrm{Ab}$ in beetles from $B t /$ non- $B t$ cornfields was likely to originate from $B t$ corn residues, which can contain $\mathrm{Cry} 1 \mathrm{Ab}$ for $>8$ months (Zwahlen et al., 2003a; 2003b), which is consistent with findings of Ahmad et al. (2005) for Cry3Bb Bt corn. Exposure may be by ingestion of residues or prey containing Cry $1 \mathrm{Ab}$. Whether living $B t$ corn plants can be a significant source of exposure remains to be determined.

Can results such as these be extrapolated to species in other regions? We suggest that a similar feeding niche may be a reasonable basis for extrapolation to other species. To get a relatively complete picture of the similarity of a feeding niche, it would be ideal to compare multiple morphological characteristics, the results of gut dissections, and biochemical analyses (Ingerson-Mahar, 2002). However, for most of the species such information will rarely be readily available. Instead, it may be sufficient only to compare the morphology of the eyes and mouthparts (Ingerson-Mahar, 2002), the diel activity pattern, and the microhabitat.

Further investigations may be needed to determine whether $B t$ corn has adverse effects on exposed ground beetles. A few studies investigated the potential effect of transgenic $B t$ plants on ground beetle populations (French et al., 2004; Lozzia and Rigamonti, 1998; Riddick et al., 1998). While Lozzia and Rigamonti (1998) did not find any significant effects of $B t$ corn $(\mathrm{Cry} 1 \mathrm{Ab})$ on the abundance of the most common carabids, French et al. (2004) found that Calosoma calidum Fabricius was less abundant in $B t$ corn $(\mathrm{Cry} 1 \mathrm{Ab})$ than in soybean, which might have been due to its high degree of specialization on lepidopteran larvae as prey. Additionally, Lebia grandis Hentz was less common in fields containing $\mathrm{Bt}$ potato (expressing the Cry3 A against the Colorado potato beetle) than in non-transgenic potato fields (Riddick et al., 1998). In a laboratory study Meissle et al. (2005) found that Poecilus cupreus L. larvae had a significantly higher mortality when fed with Cry1Ab corn-fed Spodoptera littoralis Boisduval than when fed with non- $B t$ corn-fed prey. These results suggest that some adverse effects of $B t$ crops on ground beetle abundance may be possible and need further investigation.

\section{MATERIALS AND METHODS}

\section{Fields}

The fields, from which beetles were collected for the exposure analysis, were located in the University of Minnesota Outreach, Research and Education Park,
Rosemount, Minnesota, USA. Beetles were collected from a total of 30 fields during 2003 and 2004. Median size of fields was 10.3 ha (range: $0.8-23.5$ ha). Twentythree fields contained $B t$ corn residues and four of them were planted with $B t$ corn $(B t / B t)$ when sampled, while the other nineteen were planted with non- $B t$ crops $(B t /$ non$B t$ ). The seven fields that contained non- $B t$ corn residues were planted with non- $B t$ crops when they were sampled (non- $B t /$ non- $B t$ ). All of the $B t$ corn residues and plants were varieties that expressed Cry $1 \mathrm{Ab}$, and were DKC (DeKalb) 44-42, P (Pioneer) 36R11, P 3609, K (Kaltenberg) 5454, and M (Mycogen) 4521. The non- Bt corn hybrids were DKC 440, DKC 46-28, DKC 46-26, and G (Garst) 8707.

\section{Sampling Methods}

We placed four wood boards $\left(0.3 \times 0.3 \mathrm{~m}^{2}\right)$ on the soil surface at least $15 \mathrm{~m}$ from the margin of each experimental field. The minimum distance between wood boards in adjacent fields was $50 \mathrm{~m}$ but was likely to be much larger. Approximately seven days later, we collected live adult ground beetles that were hiding under these boards. In 2003, beetles were collected in June (5th, 6th, 8th June), or July (1st, 2nd, 29th, 31st July). In 2004, ground beetles were collected in June (16th, 23rd June). Beetles were frozen in dry ice immediately upon collection in the field and brought back to the laboratory where they were stored at $-80{ }^{\circ} \mathrm{C}$ until the analyses were carried out. Using this live-catch methodology ensured that the beetles did not empty their gut before they were frozen. As a consequence, however, sample size was limited. In case that the Cry $1 \mathrm{Ab}$ exposure has a direct effect on ground beetle survival, mobility, or responsiveness to our trapping method, our live-catch methodology may have underestimated the proportion of exposed beetles.

\section{Enzyme-linked immunosorbent assay (ELISA)}

The Cry $1 \mathrm{Ab}$ concentration was quantified by ELISA as described by Gugerli $(1979,1986)$ and Zwahlen et al. (2003a, b). ELISAs were carried out on 105 samples of seven Carabidae (Coleoptera) species: Agonum placidum Say, Bembidion rupicola Kirby, Clivina impressefrons LeConte, Cyclotrachelus iowensis Freitag, Harpalus pensylvanicus DeGeer, Poecilus chalcites Say, and Poecilus lucublandus Say. Each sample consisted of one individual except for the tiny B. rupicola where one to four individuals from the same field and sample date were used per sample. Ground beetles were washed thoroughly in deionized water to remove all particles on the body surface 
of the beetles that could cause interference with the ELISA results. Microscopic examination of random samples and shams covered with pollen confirmed that washing was effective. After washing, the ground beetles were dried at room temperature for approximately one hour and weighed. The samples were prepared as described by Howald et al. (2003), except that each sample was homogenized in 0.3 to $1 \mathrm{~mL}$ extraction buffer using a pestle (EnviroLogix Inc.) and a $1.5 \mathrm{~mL}$ microcentrifuge tube. Supernatants were used for the analysis. Each sample was divided into two subsamples except for the small $C$. impressefrons, from which only one subsample could be taken.

Calibration curves were estimated on each ELISA plate using reference samples of purified, trypsin-activated Cry1 Ab suspended in extraction buffer at concentrations of $1000,100,50,20,10,5,2,1,0.5,0.2,0.1$, and $0.01 \mathrm{ng}$ Cry1Ab. $\mathrm{mL}^{-1}$. Each concentration was divided into two subsamples. Microtitre immunoassay plates Immulon ${ }^{\circledR} 4$ (Dynatech Laboratories Inc.) were analyzed with a VERSAmax microplate reader operated with the SOFTmax ${ }^{\circledR P R O} \quad 3.0$ software package (Molecular Devices Corp.). Optical density (OD) was measured at $405 \mathrm{~nm}$.

Quantitative analysis. The means of the two subsamples were used for the analysis. ODs were logtransformed and a non-linear regression was carried out to calculate the calibration curve for Cry $1 \mathrm{Ab}$ concentrations for each plate. The equation followed firstorder Michaelis-Mention kinetics:

$$
\log _{10} Y=B+(T-B) /(1+\mathrm{EC} 50 / X)
$$

where $Y$ is the optical density OD, $B$ the estimated bottom asymptote of the curve, $T$ the estimated top asymptote of the curve, EC50 the estimated response halfway between the top and bottom, and $X$ the Cry1 Ab concentration.

Detection level $(D L)$. The threshold value of detectable Cry1 Ab was defined as

$$
D L_{\mathrm{LogOD}}=B+3 * \mathrm{SE}_{B},
$$

where SE is the estimated standard error of $B$. This is approximately the upper $99 \%$ confidence interval of $B$. The threshold value was calculated separately for each immunoassay plate. Beetle samples were considered as positive when both subsamples were above the threshold and as negative when at least one of the subsamples was below the threshold.

Statistical analyses. For both hypotheses a Fisher's exact test was carried out.

\section{ACKNOWLEDGEMENTS}

We would like to thank A. Anderson, A. Schraufnagel, J. Zimmerman, L. Johnson, W. Mhlanga and K. Hasselmann for their assistance in the field and laboratory. We are grateful to J. White, M. Savanick, Y. Hu and T. Stodola, and three anonymous reviewers for their valuable comments on earlier drafts of this paper. Many thanks to W. Moar (Auburn University, USA) for the Cry1 Ab and P. Gugerli (RAC Changins, Switzerland) for providing the antiserum for the production of the antibodies. We thank R. Blahnik (University of Minnesota) and E. Hladilek (University of Kentucky, USA) for their help with the carabid indentification. This research was funded by a post-doctoral fellowship PBBEA 101094 from the Swiss National Science Foundation (SNF) and a grant-in-aid from the University of Minnesota.

Received May 4, 2005; accepted July 13, 2005.

\section{REFERENCES}

Ahmad A, Wilde GE, Zhu KY (2005) Detectability of Coleopteran-specific Cry3Bb1 protein in soil and its effect on nontarget surface and below-ground arthropods. Environ. Entomol. 34: 385-394

Clark MS, Luna JM, Stone ND, Youngman RR (1994) Generalist predator consumption of armyworm (Lepidoptera: Noctuidae) and effect of predator removal on damage in notill corn. Environ. Entomol. 23: 617-622

Dutton A, Klein H, Romeis J, Bigler F (2002) Uptake of Bttoxin by herbivores feeding on transgenic maize and consequences for the predator Chrysoperla carnea. Ecol. Entomol. 27: 441-447

French BW, Chandler LD, Ellsbury MM, Fuller BW, West M (2004) Ground beetle (Coleoptera: Carabidae) assemblages in a transgenic corn-soybean cropping system. Environ. Entomol. 33: 554-563

Gugerli P (1979) Le test immuno-enzymatique (ELISA) et son application pour le diagnostic rapide des viroses de la pomme de terre. Rev. Suisse Agric. 11: 253-260

Gugerli P (1986) Potato Viruses. In Bergmeier HU, ed, Methods of Enzymatic Analysis, VCH-Verlagsgesellschaft, Weinheim, vol XI, pp 430-446

Head G, Brown CR, Groth ME, Duan JJ (2001) Cry1 Ab protein levels in phytophagous insects feeding on transgenic corn: implications for secondary exposure risk assessment. Entomol. Exp. Appl. 99: 37-45

Hladilek EE (2003) The role of ground beetles (Coleoptera: Carabidae) in detrital food webs. M.S. thesis, University of Minnesota, St. Paul

Howald R, Zwahlen C, Nentwig W (2003) Evaluation of Bt oilseed rape on the non-target herbivore Athalia rosae. Entomol. Exp. Appl. 106: 87-93 
Ingerson-Mahar J (2002) Relating diet and morphology in adult carabid beetles. In Holland JM, ed, The Agroecology of Carabid Beetles, Intercept, Andover, pp 111-136

Kromp B (1999) Carabid beetles in sustainable agriculture: A review on pest control efficacy, cultivation impacts and enhancement. Agr. Ecosyst. Environ. 74: 187-228

Lövei GL, Sunderland KD (1996) Ecology and behavior of ground beetles (Coleoptera: Carabidae). Annu. Rev. Entomol. 41: $231-256$

Lozzia GC, Rigamonti IE (1998) Preliminary study on the effects of transgenic maize on non target species. IOBCIntegrated Control Cereal Crops 21: 171-180

Meissle M, Vojtech E, Poppy GM (2005) Effects of Bt maize-fed prey on the generalist predator Poecilus cupreus L. (Coleoptera: Carabidae). Transgenic Res. 14: 123-132

Raps A, Kehr J, Gugerli P, Moar WJ, Bigler F, Hilbeck A (2001) Immunological analysis of phloem sap of Bacillus thuringiensis corn and of the nontarget herbivore
Rhopalosiphum padi (Homoptera: Aphididae) for the presence of Cry1Ab. Mol. Ecol. 10: 525-533

Riddick EW, Dively G, Barbosa P (1998) Effect of a seed-mix deployment of Cry3A-transgenic and nontransgenic potato on the abundance of Lebia grandis (Coleoptera: Carabidae) and Coleomegilla maculata (Coleoptera: Coccinellidae). Ann. Entomol. Soc. Am. 91: 647-653

Toft S, Bilde T (2002) Carabid diets and food value. In Holland JM, ed, The Agroecology of Carabid Beetles, Intercept, Andover, pp 81-110

Wandeler H, Bahylova J, Nentwig W (2002) Consumption of two $B t$ and six non- $B t$ corn varieties by the woodlouse Porcellio scaber. Basic Appl. Ecol. 3: 357-365

Zwahlen C, Hilbeck A, Gugerli P, Nentwig W (2003a) Degradation of the Cry1 Ab protein within transgenic Bacillus thuringiensis corn tissue in the field. Mol. Ecol. 12: 765-775

Zwahlen C, Hilbeck A, Howald R, Nentwig W (2003b) Effects of transgenic Bt corn litter on the earthworm Lumbricus terrestris. Mol. Ecol. 12: 1077-1086
To access this journal online: www.edpsciences.org 